\title{
Environmental Disclosure and Financial Performance of Firms in Kenya: A Stakeholder Approach
}

\author{
Robert King'wara $^{1^{*}} \quad$ Joseph Magali $^{2} \quad$ Salum Mohamed ${ }^{2}$ \\ 1.Department of Accounting, Finance and Management Science, Egerton University, P.O. Box 13357 - 20100 \\ Nakuru, Kenya \\ 2.Faculty of Business Management, The Open University of Tanzania
}

\begin{abstract}
Using panel data analysis this study examined the influence of environmental disclosure in annual reports on financial performance of companies listed on the Nairobi Securities Exchange in Kenya. Environmental disclosure information was collected using quantitative content analysis for the period 2007-2015 while financial performance data was collected for the period 2008-2016, a one-year lag behind the environmental disclosure data. Control variables were firm size, industry type and leverage. Environmental disclosure was found to be statistically significantly positively related to the firms' return on assets but not statistically significant with return on equity and Tobin's Q. The overall results suggest that disclosing environmental activities neither improves financial performance nor deteriorates it.
\end{abstract}

Keywords: Environmental disclosure; Financial performance; Developing country; Kenya; Panel data

DOI: $10.7176 /$ RJFA/11-14-07

Publication date:July $31^{\text {st }} 2020$

\section{Introduction}

Leading companies around the world are increasingly keen on improving their business performance by acting on stakeholder concerns and measuring and reporting on both financial and non-financial information. The way an organization responds to non-financial issues increasingly determines its reputation, innovative posture, and, eventually, profitability. Environmental disclosure is the provision or communication to the stakeholders, about the impact or interaction of the organization's actions on the physical environment (Guthrie \& Mathew, 1985). Research suggests that disclosure creates a competitive advantage by linking corporate value to its values, as companies seek to position themselves as companies of choice among its stakeholders (Camilleri, 2017). Environmental disclosure encompasses issues such as climate change, resource depletion, deforestation, pollution, waste disposal, public health and energy efficiency.

Several different arguments have been advanced as to why concern for the natural environment could enhance firm financial performance. First, being proactive on environmental issues can lower the costs of complying with present and future environmental regulations (Dechant, Altman, Downing, \& Keeney, 1994; Hart, 1995; Shrivastava, 1995). Second, environmental responsiveness can enhance firm efficiencies and drive down operating costs (Russo \& Fouts, 1997; Shrivastava, 1995). Third, firms can create distinctive, "ecofriendly" products that appeal to customers, thereby creating a competitive advantage for the firms (Shrivastava, 1995). Fourth, being environmentally proactive not only avoids the costs of negative reactions on the part of key stakeholders, but can also improve a firm's image and enhance the loyalty of such key stakeholders as customers, employees, and government (Dechant et al., 1994; Hart, 1995; Shrivastava, 1995). While environmental disclosure is mandatory in developed nations such as those in the European Union, in many other parts of the world, such as Kenya it is still a voluntary initiative. By examining the effect of environmental disclosure on financial performance of companies listed on the Nairobi Securities Exchange (NSE) in Kenya this paper contributes empirical insights to the academic literature.

Worldwide, fifty percent of corporate earnings could be at risk from environmental factors according to the Principles for Responsible Investments. That translates to eleven percent of global domestic product. In addition, costs of production in eleven key industry sectors that are environmental related accounted for forty-one percent of earnings before interest, taxes, depreciation and amortization in 2010. It is becoming increasingly accepted that a significant volume of financial flows are not accounted for in corporate accounts. Furthermore, it is becoming clear that the costs of these externalities are being borne primarily by governments and society more broadly. Thus, the connection between environmental externalities and corporate value through impacts on share price are strengthening.

\section{Environmental Disclosure Development in Kenya}

Kenya is a member of United Nations Conference on Trade and Development (UNCTAD) and the Institute of Certified Public Accountants of Kenya (ICPAK) the professional body for practising auditors and accountants endorsed the International Standards of Accounting and Reporting (ISAR) rules in 2010 and started implementing them in 2011. Under the new ISAR standards, each company is expected to quantify and record as an expense the 
total damage that its operations cause to the environment. The final cost to the environment however is not deductible from the company's gross revenues for the year to determine the net profit but firms are required to balance out this cost against measures such as corporate social responsibility (CSR).

As a result of the ISAR standards, there has been an increasing trend for companies in Kenya to produce environmental information aspects of their operations. This disclosure usually takes place through environmental or sustainability reports, the Chief Executive Officer's message to shareholders, the firm's mission statement or forward looking statements in the annual reports. In 2016 the top seven listed companies in the NSE by market capitalization (61 per cent of market cap) spent a total of Ksh3 billion or an equivalent of 0.45 per cent of their total revenues on corporate social responsibility activities. At the top, Safaricom led both in percentage terms (1.18 per cent of its total revenue) and in hard figures (Ksh2.3 billion) (Mwanyasi, 2017). These Kenyan companies have disclosed their environmental activities in financial statements, websites, media and stand-alone reports.

The increased disclosure of environmental activities conflicts with the neoclassical goal of companies which views environmental expenditures and disclosures as inappropriate uses of corporate funds (Friedman, 1970). The neoclassical viewpoint holds that environmental and social issues are not the concern of businesses and environmental engagement and disclosure dilutes the company's primary objective. Given this setting, it is not clear whether environmental disclosures creates or destroys firm value. It is therefore vital empirically to identify the nature of the relationship between environmental disclosure and financial performance.

Worldwide, the results about the influence of environmental disclosure on financial performance are still inconclusive considering that there is no established relationship between environmental disclosure and financial performance (Margolis \& Walsh, 2003). Some studies have argued that there is a positive relationship between financial performance and environmental disclosure disclosure (Choi et al., 2010; Michelon, 2011). On the other hand, several studies also found a negative relationship (Mittal et al., 2008; Crisóstomo et al., 2011) while other studies' results reveal a neutral relationship (Kimbro \& Melendy, 2010, Ullmann, 1985) between environmental disclosures and financial performance. These conflicting results lead to a dilemma on the actual effect of environmental disclosure on financial performance and signify inadequacy of studies conducted into the influence of environmental disclosure on financial performance. Until a general relationship is established more research need to be conducted to resolve the observed contradictions.

As an increasing number of firms take up and disclose environmental activities, the analysis of the influence of environmental disclosure on financial performance is a consequential issue for Kenyan managers who are primarily interested in knowing if and when investment in the environment provides financial benefits to the firm. To the best of our knowledge, no research has been done in Kenya to identify the influence of environmental disclosure on financial performance using all firms in all sectors of the NSE as a sample and panel data regression for data analysis. This study fills that gap.

\section{Previous Environmental Disclosure Studies and Positioning of this Study}

The environmental disclosure and financial performance association presents some contentious arguments that, along with inconclusive empirical evidence, makes this proposed study on the subject necessary in Kenya and spurs the continuous search for answers. Over the past 40 years, many studies (Griffin \& Mahon 1997; Preston \& O‘Bannon 1997; Waddock \& Graves 1997; Ruf et al., 2001) have examined the nature of this relationship and identified various relationships.

Roberts (1992), Ullmann (1985), Wood and Jones (1995) and Preston and Post's (1975) all confirmed in their studies that environmental activities and communication impact positively on corporate financial performance. Ruf, et al (2001), investigated the relationship between environmental disclosure and corporate financial performance using stakeholder theory. The results of this study indicate that changes in environmental disclosure have a positive impact on growth in sales for current and following year. The results provide evidence of support to stakeholder theory, in that the main stakeholder group, shareholders, will gain financial benefit when organisations maintain the expectation of all shareholders.

Elijido-Ten (2007) adopted stakeholder's theory to explain environmental behaviour of Australian listed firms. His study applied three dimensional frameworks from Ullmann (1985) which included stakeholder's power, strategic posture and economic performance. Elijido-Ten's results show that the levels of environmental activities were influenced by stakeholder power (as measured by ownership dispersion, the industry sensitivity characterized by the governmental sanctions) and strategic posture (as measured by the management's concern for the environment) dimensions. The results were found to be supported by stakeholder theory, in that stakeholder power and strategic posture are important factors motivating the judgment to disclose higher environmental activities in corporate strategic plans.

Waddock and Grave's (1997) environmental disclosure and financial performance study in the United States results supported the hypothesis that financial performance is significantly dependent on environmental disclosure. This study however used data of one year (environment of 1990 and FP 1991); a longer time period may have had different findings. 
Jones et al., (2007) research investigated if there is a positive association between firm financial performance and environmental disclosure by firms using the top 100 listed companies on the Australian Securities Exchange as sample. Results indicate that environmental disclosure is positively associated with several aspects of firm financial performance, particularly: operating cash-flow performance, working capital levels, retained earnings to total assets, asset backing per share, interest cover, capital expenditure and total liabilities to total equity. However, the results showed a generally negative relationship between environmental disclosure and abnormal returns over the study period (all the t-values from the regression models were negative). But since few of the t-values were statistically significant no definite conclusion about the relationship between environmental and abnormal returns could be drawn. Therefore no general conclusion should be drawn about the relationship between environmental disclosure and all financial indicators.

Crisostomo et al., (2011) examined whether there exists a negative correlation between environmental disclosure and firm value and financial accounting performance. Results exhibited a trend toward a negative effect of environment on firm value in Brazil. The study also did not identify any significant material effect of environment on financial accounting performance. The weakness of the study is its use of the cross sectional model which lacks time element.

Saleh et al., (2011) in Malaysia measured environmental disclosure by adopting disclosure-scoring methodology based on content analysis. The financial performance measures were return on assets; the stock market return; and Tobin's q ratio. Regression equations used panel data that consisted of observations on cross sectional and time-series. Findings of the study were that the environment positively impacts on financial performance in a statistically significant manner. This study can be criticized on the ground that the sample size was drawn from the top 200 companies by market capitalizations of listed companies in Malaysia which limits the generalization of the results. The inclusion of medium-sized and small firms would have better generalized the findings.

Uwuigbe and Egbide (2012) investigated the relationship between firms' financial performance and the level of environmental disclosures among selected firms in Nigeria using linear regression model of analysis. Results of their study found a significant positive association between firms' corporate financial performance and the level of environmental disclosures among the selected listed firms. The major weakness of the study is that the selection of sampled firms was based on judgmental sampling; which was based on the nature of production, that is a firm was considered as either financial or non-financial. The approach also failed to capture all the variables at play in the different industries and firms.

Chetty et al. (2015) investigated the impact of environment factors on financial performance for the period 2004 to 2013 in South Africa by using a multi-regression data analysis. Their results revealed that environmental activities or reporting have no significant impact on firms' financial performance.

Using Johannesburg Stock Exchange's top 100 listed companies on Socially Responsible Investment Index in South Africa, Nkomani (2013) investigated the relationship between environmental disclosures and financial performance using multi-regression analysis. The findings indicated a mixture of results; in some cases a relationship was established, while in other cases there was no significant relationship.

Elouidani and Zoubir (2015) used panel data analysis to investigate the influence of environmental disclosure on financial performance FP of firms listed on the Casablanca Stock Exchange between 2007 and 2010. They found out that environmental disclosure negatively impacts the firm on its stock market performance but positively impacts on its accounting performance.

\section{Methodology}

The research hypothesis postulated that environmental disclosure has a positive and significant effect on the financial performance of companies listed on the NSE in Kenya. The study involved quantitative research methods. The implication of using quantitative methods for this study is that the design of all variables, that is, environmental disclosures, control variables and financial performance, were aimed at converting phenomena that does not exist in quantitative form into quantitative data, which could then be analyzed statistically. Research strategy was archival research. The source of data was annual reports contained in company archives. Time horizon was both cross-sectional and longitudinal research that involved quantitative research methods.

\subsection{Population of Study}

The population of this study was made up of all the companies listed on the Nairobi Securities Exchange (NSE). As at December 31, 2016, there were 64 publicly listed companies in the Nairobi Securities Exchange (NSE). The comprehensive list of companies was obtained from the NSE Handbooks for the years 2007-2016.

\subsection{Sampling Design}

Since collection and analysis of data was possible from the entire population, the study involved a census. The population of the study was restricted to those firms' whose annual reports were available either with the CMA or 
on company website. Firms with missing annual reports or delisted during the sample period or had a name change or undertook restructuring were eliminated. Those firms making environmental disclosure were thoroughly analyzed and examined. All sections of the annual report were carefully analyzed to record the incidence of environmental disclosures.

\subsection{Data Collection}

Data on both corporate social disclosure and financial performance were collected from companies' annual reports for the years 2007-2016 because they were the most recent firm results that could be easily accessed. Environmental disclosure information was collected from the companies' annual reports for the period 2007-2015. Financial data was collected for the period 2008-2016, with a one-year lag behind the environment data (for example year 2011 data for dependent variable, whilst year 2010 data for independent variables). Using time lag is in conformance with previous studies (Waddock \& Graves, 1997; Mahoney \& Roberts 2007) which explore the association between environmental disclosure and FP in the future when a firm undertakes environmental disclosure. The rationale is simple: investment in and disclosure of environment activities in the current period impacts future rather than current financial performance (Waddock \& Graves, 1997; Mahoney \& Roberts 2007).

\subsubsection{Construction of Environmental Index Using Quantitative Content Analysis}

Quantitative content analysis was used in this study to measure environmental disclosure. While there are a number of measures of reliability, Krippendorff's (1980) alpha [12] was used to assess the replicability of the results.

In order to draw valid and reliable inferences from the measurement process, the method suggested by Weber (1985) to create and test a coding scheme was followed. First, the recording units were defined. Sentences were used in this study to measure the amount of annual disclosure. It should be noted that many other studies have used measures such as words, or proportion of pages. These different measures have been found to be highly correlated (Hackston \& Milne, 1996), hence the results were not be greatly influenced by the choice of sentences instead of words, or proportion of pages.

The second step involved constructing an environmental disclosure checklist. This environmental checklist was pre-tested using the annual reports of the largest firms (in terms of capitalization) in each NSE sector. The assumption was that firms with the biggest market capitalization disclosed more than lower capitalized firms, and therefore their disclosure items covered environmental activities of smaller firms as well. After pre-testing the environmental checklist, the essential items that constitute a comprehensive environmental disclosure checklist were determined.

The last stage involved computation of the environmental index. The un-weighted disclosure index approach (Rouf 2011) was employed to measure environment disclosure level as a dichotomous variable. If a company disclosed environment items in its annual report it scored " 1 " while companies that did not disclose an item scored "0" (Gujarati, 2009). Total score values for environmental disclosure were aggregated from all sub-scores of the environment. The disclosure model scoring was additive, and the un-weighted indexes was calculated as follows to sum the final environment index for a company.

$$
E N V I=\sum_{t=1}^{n} d_{i}
$$

where, $E N V I=$ the aggregate disclosures score; $d_{i}=1$ if the item $i$ is disclosed or 0 if it is not disclosed; and $n=$ the maximum of items

\subsubsection{Financial Performance}

In line with previous studies (Hoskisson et al, 1993, this study used both accounting measures (return on assets (ROA) and return on equity (ROE) and a market value measure (Tobin's Q). These three aspects of financial performance were chosen because they not only represent both accounting and financial measures of financial performance but also they are the current common measures to examine the relationship between environmental disclosure and FP in previous studies (Griffin \& Mahon, 1997; Waddock \& Graves 1997; Tsoutsoura, 2004).

\subsection{Control Variables}

It has been suggested in several studies (Ullmann, 1985; Griffin \& Mahon, 1997; Waddock \& Graves, 1997; McWilliams \& Siegel, 2001; Clarkson et al,, 2011) that the association between a firm's financial performance and environmental disclosure is influenced by some factors such as firm size, industry type, and leverage of firm. This study introduced these variables as control variables which may have an influence between environmental disclosure and firm's financial performance.

Firm size (SIZE) was measured by the natural logarithm of market capitalization. Firm size has been found to have significant relation with environmental disclosure and financial performance (Sutantoputra et al., 2012).

The industry variable (INDUS) was defined as manufacturing and non-manufacturing industries. As suggested by Deegan and Gordon (1996), some industries may have a strong effect on the relationship between 
environmental disclosure and financial performance. For example, high profile (or environmental sensitive) industries such as mining, oil and gas industries are more likely to disclose information about their environmental activities than other industries than low-profile industries. Manufacturing was regarded "more sensitive" and comprised agricultural, construction and allied and manufacturing and allied sectors of the NSE. Nonmanufacturing was regarded "less sensitive" and was composed of the following sectors: automobiles and accessories, banking, commercial and services, energy and petroleum, insurance, investment, and telecommunication and technology. If a company belonged to manufacturing industries, the variable was set to " 1 " otherwise it is non-manufacturing and the variable was set to " 0 ".

Leverage is the use of debt to increase the potential return on investments (Zhu, Yang, An, \& Huang, 2014). High leverage ratios may deter companies from actively participating in socially responsible initiatives and thereby disclose less environmental activities. Leverage (LEV) was measured as long-term debt divided by book value of equity (Cormier et al., 2005).

\subsection{Model and Hypothesis Testing}

The first model was adopted from McWilliams and Siegel (2001), Lioui and Sharma (2012) and Lee et al (2013) in analyzing cross-sectional data to determine the relationship between the variables at one point in time. This model was used to analyse environmental disclosure financial performance link with each yearly period.

Environmental disclosure and Return on Assets (ROA) testing:

$Y_{(R O A)}=\beta_{0 R O A}+\beta_{1 R O A} E N V_{j t}+\beta_{6 R O A} S I Z E_{j t}+\beta_{7 R O A} I N D U S_{j t}+\beta_{8 R O A} L E V_{j t}+\beta_{9 R O A} C O N C_{j t}+\varepsilon_{j t}$

Environmental disclosure and Return on Equity (ROE) testing:

$Y_{(R O E)}=\beta_{O R O E}+\beta_{1 R O E} E N V_{j t}+\beta_{6 R O E} S I Z E_{j t}+\beta_{7 R O E} I N D U S_{j t}+\beta_{8 R O E} L E V_{j t}+\beta_{9 R O E} C O N C_{j t}+\varepsilon_{j t}$

Environmental disclosure and Tobin's $Q(T B Q)$ testing:

$Y_{(T B Q)}=\beta_{0 T B Q}+\beta_{1 T B Q} E N V_{j t}+\beta_{6 T B Q} S I Z E_{j t}+\beta_{7 T B Q} I N D U S_{j t}+\beta_{8 T B Q} L E V_{j t}+\beta_{9 T B Q} C O N C_{j t}+\varepsilon_{j t}$

\subsubsection{Model Specification}

The study performed a panel data regression to test the effect of environmental disclosure on financial performance. Two models of panel data models were used to estimate the data. These are the fixed effects (FE) and random effects (RE) models. Fixed effects model is represented by the following equation:

$\gamma_{i, t}=x_{i t-1} \beta+v_{i}+\mu_{i, t-1}$

Where ${ }^{\gamma_{i, t}}$ is the dependent variable (financial performance measure); $x$ represents the one-year lag of the independent variable (ENVI) and all of the control variables (SIZE, INDUS, LEV and CONC); $\beta$ is the coefficient of the independent variable and the control variables; $v$ is the unobserved firm effect; $\mu$ represents the error term; $i$ indicates a firm number; and $t$ represents time. This fixed effect model was estimated by least squares dummy variable (LSDV) regression.

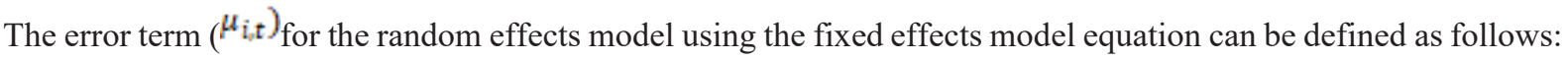
$\mu_{i, t-1}=e_{i}+v_{i, t-1}$

In equation (2), $e_{i}$ is the cross-section error component and $v_{i, t-1}$, combines the cross-section and time series error component. The random effect model was estimated by generalized least squares (GLS). To decide between random and fixed effects models, both models were run and then the Hausman test was performed.

\section{Discussion on Findings}

\subsection{Descriptive Statistics}

Refer to Table 1 for results. ROA had a mean of 7.021318, and a standard deviation of 12.10162. Both mean and standard deviation for ROA are lower than for ROE and TBQ because the longer the period over which ROA is measured the less variable it is likely to be (subject to major strategic shifts in firms' direction and performance). The minimum value was negative 30.91 which clearly means that there are some firms which made losses and the maximum value was positive 65.9 an indicator of positive profits made over the study period.

Average ROE was 12.53096 and the standard deviation recorded was 78.36588. ROE standard deviation depicts higher dispersion than ROA standard deviation. ROE dispersion provides an aggregate measure of comovement in the NSE portfolio for the time period under study and carries reliable information regarding the state of the economy (economic expansions and recessions). ROE is a measure of efficiency; high ROE's suggest firm's ability to generate profits without needing as much equity capital to finance their operations.

Tobin's Q for all firms under study recorded a mean of 85.19237 and a standard deviation of 561.5627 while the minimum value was -0.2 and a maximum value of 4913.61 . The highest standard deviation for financial performance variables was the Tobin's Q (561.5627), suggesting that the difference among the firms was highest in this financial performance indicator. Generally, firms that disclose environmental issues more are larger, more profitable and higher in TBQ. 
Environment disclosure registered a mean of 4.054321 and the standard deviation of 2.96548 . The mean was slightly higher than that of employee and community which means environment has a high contribution on financial performance compared with the other previous variables.

The control variable SIZE measured by the natural logarithm of market capitalization, had an average of 9.68672 (antilog: Sh. 4,860,937,084) with a standard deviation of 0.9288673 . The minimum value was 6.134241 (antilog: Sh. 1,362,200) and the maximum score was 11.4032 (antilog: Sh. 253,046,304,946). From the stakeholder theory it is expected that environmental disclosure positively affects firm performance because it helps firms gain positive stakeholder responses. The study depicts firms listed on the NSE had good market capitalization as indicated by a mean of 9.68672 (antilog: Sh. 4,860,937,084).

Industry was measured by scores allocated, where a score of " 1 " was allocated for manufacturing the variable and non-manufacturing and the variable was set to " 0 ". The study recorded a mean of 0.4 and the standard deviation was 0.4905039 which depicts a least dispersion between the manufacturing proxied by 1 and the nonmanufacturing measured using a score of 0 . A mean of 0.4 means that on average most firms are in the nonmanufacturing category. It is expected that industry membership is positively and significantly correlated with environmental disclosure (Monteiro \& Guzman, 2010). Manufacturing is regarded as more sensitive and nonmanufacturing less sensitive to environmental disclosure. The maximum value was 1 and the minimum stands at 0 .

The average leverage ratio 149.3729 highlights the likelihood of NSE listed companies to finance assets and or operations by use of liabilities instrument. Leverage affects shareholders' returns. The standard deviation is 122.7223 while minimum and maximum values recorded are 0 and 610.66 respectively.

Concentration recorded a mean of 1 which indicated firms had a majority shareholder (i.e. a shareholder with more than $25 \%$ or more of the voting shares). The standard deviation was 0 which indicate no dispersion between the variables since the variable fetched a score of 1 . The maximum and the minimum value was 1 .

Table 1: Descriptive Statistics

\begin{tabular}{lllll}
\hline & Mean & Sd & Min & Max \\
\hline Envir & 4.054321 & 2.96548 & 0 & 8 \\
Roa & 7.021318 & 12.10162 & -30.91 & 65.9 \\
Roe & 12.53096 & 78.36588 & -1006.74 & 625.62 \\
Tbq & 85.19237 & 561.5627 & -.2 & 4913.61 \\
Size & 9.68672 & .9288673 & 6.134241 & 11.4032 \\
Indus & .4 & .4905039 & 0 & 1 \\
Lev & 149.3729 & 122.7223 & 0 & 610.66 \\
Conc & 1 & 0 & 1 & 1 \\
\hline
\end{tabular}

\subsection{The Reliability Measure Results}

The study used the content analysis approach and specifically the Krippendorff's alpha (Krippendorff, 1980). Krippendorff's alpha typically ranges from 0 to 1, with 1 indicating perfect reliability and 0 indicating the absence of reliability (Krippendorff, 2011). The alpha estimates were produced using ratings from two judges. An overall alpha of 0.9767 was found. According to Krippendorff (2004), the Krippendorff alpha should be above 0.8 to indicate appropriate reliability measures. The results of the Krippendorff alpha in this study show high reliability over all the years of the period.

\subsection{Diagnostic Tests}

There are several assumptions underlying multiple regression analysis that have to be satisfied for the regression model to be valid. One of them was to test whether the assumption of homoscedasticity was valid or not. The other was to test for multicollinearity.

\subsubsection{Test for Homoscedasticity}

To test for heteroscedasticity, Breusch and Pagan test was conducted to test the null hypothesis that the error terms have constant variance or are homoscedastic versus the alternative that the error variances are a multiplicative function of one or more variables. A large chi-square would indicate that heteroscedasticity was present.

All the models were found to be heteroscedastic and the least squares estimates are not efficient. To remedy this issue, the analysis controlled for heteroscedasticity to provide a better fit for the model by using robust standard errors in all models. 
Table 2: Breusch and Pagan Heteroscedasticity Test

\begin{tabular}{llll}
\hline & Breusch-Pagan Test & & \\
\hline & Test Statistic & p-value & Heteroscedastic \\
\hline Model 1 & 5.96 & 0.0146 & Yes \\
Model 2 & 537.79 & $<0.0000$ & Yes \\
Model 3 & 9.80 & 0.0017 & Yes \\
\hline
\end{tabular}

\subsubsection{Test for Multicollinearity}

The other routine test is to check for the presence of multicollinearity. The multicollinearity is tested to identify that the independent variables are not highly correlated in the explanatory variables. To do so, the matrix of correlation between the explanatory variables were computed and the results are summarized in Table 3 .

Table 3: Correlation Matrix for the Explanatory Variables

\begin{tabular}{lllll} 
& Environment & Firm Size & Industry & Leverage \\
Environment & 1 & & & \\
Firm Size & 0.583 & 1 & 1 & \\
Industry & -0.177 & -0.259 & -0.210 & 1 \\
Leverage & 0.156 & 0.369 & 1 \\
\hline
\end{tabular}

There is no issue of multicollinearity, as the correlation does not exceed 0.70 .

\subsubsection{Hausman Test}

This test compares the consistent fixed effects model with the efficient random effects model. Fixed effects models were ran and estimates saved; then random effects models were ran and estimates saved; then the Hausman test was performed. The Hausman tests for the three models are summarized in tables 4.

Interpretation of results: If the $p$-value is significant $(p<0.05)$ then use fixed effects, if not $(p>0.05)$ use random effects (Greene, 2018). The random effects model is adopted for the panel analysis since it gives a more robust estimation of the model than the fixed model.

Table 4: Hausman Test

\begin{tabular}{|l|c|c|c|}
\hline Dependent variable & Chi square value & p value & Model to choose \\
\hline ROA & 3.17 & 0.3667 & $\mathrm{RE}$ \\
\hline ROE & 0.78 & 0.9976 & $\mathrm{RE}$ \\
\hline T BQ & 13.95 & 0.0520 & $\mathrm{RE}$ \\
\hline
\end{tabular}

\subsection{Panel Data}

In this part we regressed the three financial performance measures on the environmental disclosure. The firms' unobserved specific effects entered the model as an error component as shown in the following expressions. The following models were estimated:

$$
\begin{aligned}
& Y_{(R O A) \text { it }}=\beta_{O R O A}+\beta_{1 R O A} E N V_{i t}+\beta_{6 R O A} S I Z E_{i t}+\beta_{7 R O A} I N D U S_{i t}+\beta_{8 R O A} L E V_{i t}+\left(\varepsilon_{(R O A) i t}+\mu_{i R O A}\right) \\
& Y_{(R O E) \text { it }}=\beta_{O R O E}+\beta_{1 R O E} E N V_{i t}+\beta_{6 R O E} S I Z E_{i t}+\beta_{7 R O E} I N D U S_{i t}+\beta_{8 R O E} L E V_{i t}+\left(\varepsilon_{(R O E) \text { it }}+\mu_{i R O E}\right) \\
& Y_{(T B Q) \text { it }}=\beta_{O T B Q}+\beta_{1 T B Q} E N V_{i t}+\beta_{6 T B Q} S I Z E_{i t}+\beta_{7 T B Q} I N D U S_{i t}+\beta_{8 T B Q} L E V_{i t}+\left(\varepsilon_{(T B Q) \text { it }}+\mu_{i T B Q}\right)
\end{aligned}
$$

5.4.1. Environmental Disclosure and Return on Assets (ROA)

The results of the first regression shown in Table 5 indicate that the environmental dimension of the corporate social responsibility disclosure is statistically positively related to the firms' return on assets. On the other hand, the firm's size and the type of industry have a positive and statistically significant impact on firm's return on assets. In term of variance, the variance due to the difference between firms contributes more than $44 \%$ in the total variance of the model.

The Breusch and Pagan Lagrange multiplier test results rejects the pooled model in favor of the random effects model; while the Hausman test confirms once again the consistency of the random effects. 
Table 5: Results of ENVI Disclosure for ROA

\begin{tabular}{lllll}
\hline & Estimate & Std.error & $t$-value & $p-$ value \\
\hline Environment & 0.9860 & 0.5636 & 1.7493 & 0.0802 \\
Firm Size & $3.3219^{*}$ & 1.3012 & 2.5530 & 0.0107 \\
Industry & $6.7935^{*}$ & 2.7168 & 2.5006 & 0.0124 \\
Leverage & $-0.0292^{* * *}$ & 0.0062 & -4.7043 & 0.0000 \\
Constant & $-24.2930^{*}$ & 11.7539 & -2.0668 & 0.0388 \\
\hline Observations & 405 & & \\
$\mathrm{R}^{2}$ within & 0.0605 & & \\
$\mathrm{R}^{2}$ between & 0.3246 & & \\
$\mathrm{R}^{2}$ overall & 0.2055 & & \\
Breusch and Pagan Lagrange Multiplier Test & $\mathrm{X}^{2}(1)=239.18$ & & \\
Breusch and Pagan Lagrange Multiplier Test & $\mathrm{p}-$ value $<0.0000$ & & \\
Hausman Test of Consistency of Random Effects & $\mathrm{x}(3)=6-51$ & & \\
Hausman Test of Consistency of Random Effects & $p-$ value $=0.4812$ & & & \\
\hline
\end{tabular}

\subsubsection{Environmental Disclosure and Return on Equity (ROE)}

When the return on equity is used as the dependent variable, once again no variable is statistically significant except the firm size. Moreover, the pooled model is rejected in favor of its counterpart the random effects model according to the Breusch Pagan Lagrange multiplier test. The Hausman test shows that the random model is still consistent. The variance due to firms' specific effect does not represent more than $2 \%$ of the total variance. See Table 6 for the results of random effects model with environmental disclosure against ROE.

Table 6: Results of ENVI for ROE

\begin{tabular}{lllll}
\hline & Estimate & Std.error & $t$-value & $p$-value \\
\hline Environment & 0.7058 & 2.1578 & 0.3271 & 0.7436 \\
Firm Size & $24.2908^{* * *}$ & 6.3233 & 3.8415 & 0.0001 \\
Industry & 9.5556 & 9.2170 & 1.0367 & 0.2999 \\
Leverage & $-0.0856^{*}$ & 0.0372 & -2.3016 & 0.0214 \\
Constant & $-209.4243^{* * *}$ & 55.5900 & -3.7673 & 0.0002 \\
\hline Observations & 405 & & \\
$R^{2}$ within & 0.0071 & & \\
$R^{2}$ between & 0.4125 & & \\
$R^{2}$ overall & 0.0717 & & \\
Breusch and Pagan Lagrange Multiplier Test & $\mathrm{X}^{2}(1)=0.18$ & & \\
Breusch and Pagan Lagrange Multiplier Test & $\mathrm{p}-$ value $=0.3352$ & & \\
\hline Hausman Test of Consistency of Random Effects & $\mathrm{x}(1)=0.77$ & & \\
Hausman Test of Consistency of Random Effects & $\mathrm{p}-$ value $=0.9978$ & & \\
\hline
\end{tabular}

\subsubsection{Environmental Disclosure and Tobin's Q (TBQ)}

Finally, the regression where the Tobin's Q is used as a measure of financial performance is estimated and the results are presented in the Table 7 . Though the variance of the firms' specific effects represents more than $96 \%$ of the total variance, the results of this model does not yield any statistically significant relationship between environmental disclosure and the firms' financial performance, measured by Tobin Q. Once again, only the firm's size has a positive and statistically significant effect on Tobin's Q; this is despite the fact that the random effects model is statistically more efficient than the pooled model as evidenced by the Breusch and Pagan Lagrange multiplier test. 
Table 7: Results of ENVI for TBQ

\begin{tabular}{lllll}
\hline & & Tobin Q & & \\
& Estimate & Std.error & t-value & $p$-value \\
\hline Environment & -2.5196 & 11.9682 & -0.2105 & 0.8333 \\
Firm Size & $60.4982^{* *}$ & 19.3040 & 3.1340 & 0.0017 \\
Industry & 214.3185 & 158.6850 & 1.3506 & 0.1768 \\
Leverage & 0.0017 & 0.0780 & 0.0223 & 0.9822 \\
Constant & $-580.8096^{* *}$ & 212.7937 & -2.7294 & 0.0063 \\
\hline Observations & 405 & & & \\
$\mathrm{R}^{2}$ within & 0.0254 & & \\
$\mathrm{R}^{2}$ between & 0.0236 & & \\
$\mathrm{R}^{2}$ overall & 0.0232 & & \\
\hline BP Lagrange Multiplier Test & $\mathrm{X}^{2}(1)=1381.30$ & & \\
BP Lagrange Multiplier Test & $p-$ value $<0.0000$ & & \\
Hausman Test & $\mathrm{X}^{2}(3)=19.38$ & & \\
Hausman Test & $\mathrm{p}-$ value $=0.017$ & & \\
\hline
\end{tabular}

\subsection{Summary of Hypotheses' Tests Results}

In conclusion, the environmental disclosure is statistically positively related to ROA. For ROE, no variable is statistically significant except the firm size. For the TBQ equation, only the firm size has a positive and statistically significant effect on TBQ.

Table 8: Results of the Random Effects Model with Environmental Disclosure

\begin{tabular}{|c|c|c|c|c|c|c|}
\hline & \multicolumn{2}{|c|}{ Return on Assets } & \multicolumn{2}{|c|}{ Return on Equity } & \multicolumn{2}{|l|}{ Tobin Q } \\
\hline Environment & 0.986 & 1.75 & 0.706 & 0.33 & -2.520 & -0.21 \\
\hline Firm Size & $3.322 *$ & 2.55 & 24.29 & 3.84 & 60.50 & 3.13 \\
\hline Industry & $6.793 *$ & 2.50 & 9.556 & 1.04 & 214.3 & 1.35 \\
\hline Leverage & $-0.0292 * * *$ & -4.70 & -0.0856 & -2.30 & 0.00174 & 0.02 \\
\hline Constant & $-24.29 *$ & -2.07 & -209.4 & -3.77 & -580.8 & -2.73 \\
\hline Observations & 405 & & 405 & & 405 & \\
\hline $\mathrm{R}^{2}$ within & 0.0605 & & 0.0071 & & 0.0254 & \\
\hline $\mathrm{R}^{2}$ between & 0.3246 & & 0.4225 & & 0.0236 & \\
\hline $\mathrm{R}^{2}$ overall & 0.2055 & & 0.0717 & & 0.0232 & \\
\hline Breusch and Pagan Lagrange Multiplier & & & & & & \\
\hline Test & $x_{(1)}^{2}=239.18$ & & $x_{(1)}^{2}=0.18$ & & $x_{(1)}^{2}=1381.30$ & \\
\hline Breusch and Pagan Lagrange Multiplier & p-value $<$ & & p-value $<$ & & p-value $<$ & \\
\hline Test & 0.0000 & & 0.3352 & & 0.0000 & \\
\hline $\begin{array}{l}\text { Hausman Test of Consistency of } \\
\text { Random Effects }\end{array}$ & $x_{(3)}^{2}=6.51$ & & $x_{(3)}^{2}=0.77$ & & $x_{(3)}^{2}=19.38$ & \\
\hline Hausman Test of Consistency of & $\mathrm{p}$-value $=$ & & p- & & & \\
\hline Random Effects & 0.4812 & & value $=0.9978$ & & p-value $=0.017$ & \\
\hline
\end{tabular}

$t$ statistics in second column

$* p<0.05, * * p=0.01, * * * p<0.001$

\section{Conclusion}

The overall objective of the study was to examine the influence of environmental disclosure on financial performance of companies listed on the NSE. Following the literature, three measures of financial of financial performance were proposed: firms' return on assets, firms' return on equity, and firms' Tobin Q.

The results indicate that the environmental dimension of the corporate social responsibility disclosure is statistically positively related to the firms' ROA but yields no statistically significant relationship with ROE and TBQ. The results agree with those of Schreck (2011) who also found a positive relationship between ROA and the environment disclosure theme. The findings are also consistent with other research which showed no relationship between environmental disclosure and ROE and TBQ (Korathotage, 2012). However the findings do not corroborate the results of Hossain et al,. (1994) who suggests that there is a positive and significant relationship between environmental disclosure and ROE. A possible explanation for this could be due to the fact that the definition of environmental disclosure by country was different (Griffin and Mahon, 1997). For example, carbon dioxide emission levels disclosures while a concern in the developed countries is not as important as afforestation disclosures in Kenya.

The overall results suggest that disclosing environmental activities neither improves profitability nor 
deteriorates it. This could possibly be due to the presence of a complex relationship between environmental disclosure and financial performance. The outcome may also suggest that firms may be failing to effectively communicate the positive effects of their environmental initiatives to their investors.

One major implication of this research is that it does not support the argument that environmental disclosure positively impacts financial performance in line with the stakeholder theory. However, environmental disclosure has a positive and statistically significant impact on the return on assets variable. This has implications for academics, managers and other stakeholders. For academics, the work broadens the analysis of the environmental disclosure financial performance within developing countries. For managers, environmental disclosure in financial statements though informative is shown as lacking credibility in influencing financial performance. Therefore commitment to higher financial quality by inclusion of environmental disclosure does not bring positive financial results. Policy makers within government who would like to see more private sector involvement in societal issues will take note that such engagement has no positive impact on corporate financial outcomes.

The study makes the following two recommendations: First, environmental disclosure should continue to be voluntary in Kenya; calls from some stakeholders for mandatory disclosures should not be heeded. Secondly, financial managers should ignore pressure from stakeholders to pursuit and disclose more environmental activities because environmental disclosures do not add value to the firm.

This paper adds to the sparse research on environmental disclosure - financial performance relationship in developing countries by focusing on firms listed in Kenya's NSE which contribute immensely to the development of the Kenyan economy. The study also makes an important contribution to the literature of environmental disclosure, especially in relation to stakeholder theory. Previous studies have revealed mixed results of the relationship between environmental disclosure and company financial performance.

A number of important limitations need to be considered. Firstly, this study examined company annual reports based over a ten-year period, 2007-2016 only. There were 46 companies included in the sample for each year. A longer period of study, for example, thirty years may produce different results. Secondly, this study only focused on company annual reports, which may show an incomplete picture of environmental disclosure practice of companies in Kenya. Companies may report environmental activities in other media like sustainability reports, environmental reports, interim reports, newspapers, advertising, promotional leaflets, websites, or company brochures. This study is limited to the data from annual reports of NSE listed firms.

The study examined the relationship between environmental disclosures and financial performance of 46 companies listed on the NSE between 2007 and 2016. Future research could apply a longitudinal method by using more years' data and a larger sample size. This would increase the reliability of the results. The study is limited to three finance performance indicators, which are ROA, ROE and TBQ. Use of more financial performance indicators (both accounting-based and market-based performance, e.g., stock return, price earnings ratio, market to book value) and inclusion of variables that cover research and development and advertising intensity (McWilliams \& Siegel, 2001) and management quality (García-Castro et al., 2010) may yield different results.

\section{References}

Camilleri, M.A. (2017). Corporate sustainability and responsibility: creating value for business, society and the environment. Asian Journal of Sustainability and Social Responsibility 2, 59-74.

Chetty, S., Naidoo, R., \& Seetharam, Y. (2015). The Impact of Corporate Social Responsibility on Firms' Financial Performance in South Africa. Contemporary Economics, 9(2), 193-214.

Choi, J-S., Kwak, Y-M., \& Choe, C. (2010). Corporate Social Responsibility and Corporate Financial Performance: Evidence from Korea. Australian Journal of Management, 35(3), 291- 311.

Clarkson, P. M., Overell, M. B., \& Chapple, L. (2011). Environmental Reporting and its Relation to Corporate Environmental Performance. Abacus, 47, 27-60.

Cormier, D., Magnan, M., \& Velthoven, B. V. (2005). Environmental Disclosure Quality in Large German Companies: Economic Incentives, Public Pressures or Institutional Conditions? European Accounting Review, 14(1), 3-39.

Crisóstomo, V.L., Freire, F.S., \& Vasconcellos, F.C. (2011). Corporate Social Responsibility, Firm Value and Financial Performance in Brazil. Social Responsibility Journal, 7(2), 295 - 309.

Dechant, K., Altman, B., M. Downing, R. M., Timothy, Keeney, T. (1994). Environmental Leadership: From Compliance to Competitive Advantage [and Executive Commentary]. The Academy of Management Executive (1993-2005), 8(3), 7-27.

Deegan, C., \& Gordon, B. (1996). A study of the environmental disclosure practices of Australian corporations. Accounting and Business Research, 26(3), 187-199.

Elijido-Ten, E. (2007). Applying stakeholder theory to analyze corporate environmental performance: Evidence from Australian listed companies. Asian Review of Accounting, 15, 2, 164-184.

Elouidani, A., \& Zoubir, F. (2015). Corporate social responsibility and financial performance. African Journal of Accounting, Auditing and Finance, 4(1), 74-85. 
Friedman, M. (1970). The Social Responsibility of Business Is to Increase Its Profits. Corporate Ethics and Corporate Governance, 173-178.

Garcia-Castro, R., Arino, M. A., \& Canela, M. A. (2010). Does social performance really lead to financial performance? Accounting for endogeneity. Journal of Business Ethics, 92, 1, 107-126

Griffin, J. J., \& Mahon, J. F. (1997). The Corporate Social Performance and Corporate Financial Performance Debate: Twenty-Five Years of Incomparable Research. Business \& Society, 36 (1), 5-31.

Gujarati, D. N. (2009). Basic Econometrics. Boston: McGraw-Hill Irwin.

Guthrie, J.E., \& Mathews, M.R. (1985). Corporate social accounting in Australasia. Research in Corporate Social Performance and Policy, 7, 251-77.

Hackston, D., \& Milne, M. (1996). Some determinants of social and environmental disclosures in New Zealand companies. Accounting, Auditing \& Accountability Journal, 9(1), 77-108.

Hart, S. (1995). 'A natural resource-based view of the firm. Academy of Management Review, 20, 986- 1014.

Kimbro, M. B., \& Melendy, S. R. (2010). Financial Performance and Voluntary Environmental Disclosures During the Asian Financial Crisis: The Case of Hong Kong. International Journal of Business Performance Management, 12 (1), 72-85.

Korathotage, K. T. (2012). Corporate social responsibility and company performance: Evidence from Sri Lanka.

Krippendorff, K. (1980). Content Analysis: An Introduction to its Methodology. Beverly Hills: Sage.

Krippendorff, K. (2004). Content analysis: An Introduction to its Methodology. Sage Publications, London.

Krippendorff, K. (2011). Agreement and Information in the Reliability of Coding. Communication Methods and Measures, 5(2), 93-112.

Lee, S., Singal, M., and Ho Kang, K. (2013). The corporate social responsibility -financial performance link in the U.S. restaurant industry: Do economic conditions matter? International Journal of Hospitality Management, 32: 2- 10.

Lioui, A. and Sharma, Z. (2012). Environmental corporate social responsibility and financial performance: Disentangling direct and indirect effects. Ecological Economics, 78: 100-111.

Mahoney, L., \& Roberts, R. W. (2007). Corporate Social Performance, Financial Performance and Institutional Ownership in Canadian firms. Accounting Forum, 31(3), 233-253.

Margolis, J. D., \& Walsh, J. P. (2003). People and Profits?: The Search for a Link Between a Company's Social and Financial Performance. Mahwah, NJ: Lawrence Erlbaum Associates.

McWilliams, A., \& Siegel, D. (2001). Corporate Social Responsibility and Financial Performance: Correlation or Misspecification? Strategic Management Journal, 21, 603-609.

Michelon, G. (2011). Sustainability Disclosure and Reputation: A Comparative Study. Corporate Reputation Review, 14 (2), 79-96.

Mittal, R.K., Sinha, N., \& Singh, A. (2008). An analysis of Linkage Between Economic Value Added and Corporate Social Responsibility. Management Decision, 46 (9), 1437 - 1443.

Mwanyasi, R. (2017, August 1). Why Every Firm Should Give Back to Community. Business Daily. Retrieved from http://www.businessdailyafrica.com/analysis/Why-every-firm-should-give-back-tocommunity/539548-4041050-twxbdc/index.html

Nkomani, S. (2013). Corporate Social Responsibility and Financial Performance: The Johannesburg Stock Exchange Top 100. Unpublished dissertation, University of Pretoria. Retrieved from repository.up.ac.za/handle/2263/26367. Retrieved on 17/05/2017.

Preston, L. E., \& O’Bannon D. P. (1997). The Corporate Social-Financial Performance Relationship: A Typology and Analysis. Business and Society 36 (4), 419-429.

Preston, L. E., \& Post, J. E. (1975). Private management and public policy: The principle of public responsibility. Englewood Cliffs, N.J: Prentice-Hall.

Roberts, R. W. (1992). Determinants of Corporate Social Responsibility Disclosure: An Application of Stakeholder Theory. Accounting, Organizations and Society, 17(6), 595-612.

Rouf, M. A. (2011). The Corporate Social Responsibility Disclosure: A Study of Listed Companies in Bangladesh. Business and Economics Research Journal, 2 (3), 19-32.

Ruf, B. M., Muralidhar, K., Brown, R. M., Janney J. J., \& Paul K. (2001). An Empirical Investigation of the Relationship Between Change in Corporate Social Performance and Financial Performance: A Stakeholder Theory Perspective. Journal of Business Ethics, 32 (2), 143-156. doi: 10.2307/25074563

Russo, M., \& Fouts, P. (1997). A Resource-Based Perspective on Corporate Environmental Performance and Profitability. The Academy of Management Journal, 40(3), 534-559.

Saleh, M., Zulkifli, N., \& Muhamad, R. (2011). Looking for Evidence of the Relationship Between Corporate Social Responsibility and Corporate Financial Performance in an Emerging Market. Asia-Pacific Journal of Business Administration, 3(2), 165-190.

Schreck, P. (2011). Reviewing the Business Case for Corporate Social Responsibility: New Evidence and Analysis. Journal of Business Ethics, 103, 2, 167-188. 
Shrivastava, P. (1995). The Role of Corporations in Achieving Ecological Sustainability. The Academy of Management Review, 20, 4, 936-960.

da Silva Monteiro, S. M., \& Aibar-Guzman, B. (2010). Determinants of environmental disclosure in the annual reports of large companies operating in Portugal. Corporate Social Responsibility and Environmental Management, 17(4), 185-204.

Sutantoputra, A. W., Lindorff, M., \& Johnson, E. P. (2012). The relationship between environmental performance and environmental disclosure. Australasian Journal of Environmental Management, 19, 1, 51-65.

Tsoutsoura, M. (2004). Corporate Social Responsibility and Financial Performance. University of California, Berkeley.

Ullmann A. A. (1985). Data in Search of a Theory: A Critical Examination of the Relationships Among Social Performance, Social Disclosure, and Economic Performance of U.S. Firms. Academy of Management Review, $10(3), 540-557$.

Uwuigbe, U., \& Egbide, B. C. (2012). Corporate social responsibility disclosure in Nigeria: A study of listed financial and non-financial firms. Journal of Management and Sustainability, 2(1), 160-168.

Waddock, S. A., \& Graves, S. B. (1997). The Corporate Social Performance-Financial Performance Link. Strategic Management Journal, 18, 303-319.

Weber, R. P. (1985). Theory and Methods of Scaling, New York, NY, Wiley.

Wood, D. J., and R. E. Jones (1995). Stakeholder Mismatching: A Theoretical Problem in Empirical Research on Corporate Social Performance. The International Journal of Organizational Analysis, 3(3), 229-267.

Zhu, C., Yang, G., An, K., \& Huang, J. (2014). The Leverage Effect on Wealth Distribution in a Controllable Laboratory Stock Market. Plos One, 6. 